\title{
Pathogenesis of Simian Immunodeficiency Virus Pneumonia
}

\section{An Immunopathological Response to Virus}

\author{
Joseph L. Mankowski, ${ }^{, \dagger}$ Darryl L. Carter, ${ }^{* \dagger}$ \\ Jeffrey P. Spelman, ${ }^{*}$ Michele L. Nealen, ${ }^{*}$ \\ Kevin R. Maughan, ${ }^{*}$ Lynn M. Kirstein, ${ }^{\neq}$ \\ Peter J. Didier, ${ }^{\S}$ Robert J. Adams, ${ }^{*}$ \\ Michael Murphey-Corb, ${ }^{\S}$ and M. Christine Zink*†ף \\ From the Division of Comparative Medicine* and Department of \\ Pathology, Johns Hopkins University School of Medicine, \\ Baltimore, Maryland; Departments of Epidemiology ${ }^{\ddagger}$ and \\ Molecular Microbiology and Immunology, "Johns Hopkins School \\ of Public Health, Baltimore, Maryland; and Tulane Regional \\ Primate Research Center, ${ }^{\S}$ Covington, Louisiana
}

virus pneumonia may represent an immunopathological response to macrophage-tropic virus. ( $\mathrm{Am} J$ Patbol 1998, 153:1123-1130)

Lymphocytic interstitial pneumonia (LIP) is a common manifestation of human immunodeficiency virus (HIV) infection, affecting from 30 to $50 \%$ of children perinatally infected with HIV, and a smaller percentage of adults., ${ }^{1,2}$ Despite this high incidence, the role of host and viral factors in the onset and progression of pulmonary disease is not well understood. LIP is characterized by diffuse, pleomorphic interstitial infiltrates of lymphocytes, plasma cells, and macrophages, with CD8+ lymphocytes specific for HIV constituting a large proportion of the infiltrating lymphocyte population. ${ }^{3-5}$ The histopathological changes of LIP resemble the interstitial pneumonia found in autoimmune disorders such as Sjögren's syndrome and systemic lupus., ${ }^{6,7}$ Several studies have demonstrated that HIV-infected children with LIP have a lower incidence of opportunistic infections and a longer survival time than children seropositive for HIV who do not develop primary pneumonia. ${ }^{8-10}$

Another HIV-associated pulmonary condition, diffuse infiltrative lymphocytosis syndrome (DILS), affecting mainly HIV-positive African Americans, is characterized by diffuse interstitial infiltrates of CD8 $+T$ cells in the lungs and in other organs. Like LIP, DILS is associated with infection by macrophage-tropic strains of HIV, and affected individuals have fewer opportunistic infections and prolonged survival. ${ }^{11-14}$ Studies have suggested that DILS, which has been associated with HLA-DR5, may represent a specific host response against macrophage-tropic HIV.

The simian immunodeficiency virus (SIV)/macaque model provides several advantages for studying the pathogenesis of HIV pneumonia. Like HIV, replication of SIV in macrophages is thought to be responsible for

Supported by Grants HL53248, HL35344, RR00116, NS07392, and RR07002 from the National Institutes of Health.

Accepted for publication June 29, 1998.

Address reprint requests to Dr. M. C. Zink, Division of Comparative Medicine, Johns Hopkins University School of Medicine, Traylor G-60, 720 Rutland Avenue, Baltimore, MD 21205. E-mail: mczink@welchlink. welch.jhu.edu. 
pulmonary disease, whereas SIV replication in lymphocytes results in immunosuppression and opportunistic infections. ${ }^{11-13,15,16}$ Of particular importance, macaques can be inoculated with molecularly cloned, biologically characterized strains of SIV and examined throughout infection to study the pathogenesis of disease caused by specific viral strains.

In this study, 20 macaques were inoculated with related macrophage-tropic strains of SIV and euthanized 2 months or more after inoculation. Pulmonary histopathology was compared with expression of viral RNA and protein to determine whether severity of pulmonary lesions was related to the level of virus replication in the lung.

\section{Materials and Methods}

\section{Viruses}

The macrophage-tropic strains SIV/R71 and 17E-Br were obtained by serial intracerebral passage of SIVmac239 in rhesus macaques. ${ }^{17}$ SIV/R71 and SIV/17E-Br are closely related virus strains, with almost identical env sequences, and both replicate productively in brain macrophages. ${ }^{17,18}$ The recombinant molecular clone SIV/ $17 \mathrm{E}-\mathrm{Cl}$ was constructed by inserting the surface glycoprotein of SIV/17E-Br into the backbone of SIVmac239. ${ }^{18}$ The recombinant molecular clone SIV/17E-Fr was made by inserting the entire envelope gene, the nef gene, and the $3^{\prime}$ long terminal repeat of SIV/17E-Br into the backbone of SIVmac239. ${ }^{18,19}$ Because sequence changes present in the long terminal repeat of SIV/17E-Br overlapped with nef, SIV/17E-Cl and SIV/17E-Fr were congenic except for the transmembrane portion of env and the nef gene. Both recombinant viruses were determined to be macrophage-tropic by their ability to replicate to high titers in primary rhesus blood-derived macrophages and their inability to replicate in T cell lines. ${ }^{19}$

\section{Animals}

Nineteen macaques were inoculated intravenously via the saphenous vein or via bone marrow inoculation per the doses previously described. ${ }^{17,20}$ Macaque 17E was inoculated intracerebrally, a route in which much of the inoculum enters peripheral blood. ${ }^{17,18}$ Species inoculated included Macaca mulatta (rhesus macaques), $M$. nemestrina (pig-tailed macaques), and $M$. fascicularis (cynomolgus macaques), all species known to be susceptible to SIV infection. ${ }^{21}$ Lysates of peripheral blood leukocytes from all inoculated macaques were positive for SIV by polymerase chain reaction amplification. Animals were observed daily and euthanized if they manifested clinical signs of disease (weight loss greater than $15 \%$, persistent diarrhea, neurological signs, CD4+ cell count decline to less than $5 \%$ of baseline, or opportunistic infections). Macaques that did not develop clinical signs of disease were euthanized at 9 months after inoculation or later. Peripheral blood was taken from macaques 9001, 9002, 9003, 9101, and 9102 (group 1) every week for the 1st month after inoculation and ap- proximately monthly thereafter. Buffy coat cells were labeled with fluorochrome-conjugated monoclonal antibodies against CD4 (OKT4, Coulter, Hialeah, FL) to quantitate CD4+ lymphocytes as previously described. ${ }^{22}$ These five macaques were monitored for 2 years postinoculation.

\section{Histopathological Assessment and Scoring}

Before necropsy, animals were perfused with sterile 0.9\% saline to remove SIV-infected peripheral blood leukocytes from lung and other tissues. Tissues were fixed in Streck tissue fixative (Streck Laboratory, Omaha, NE), embedded in paraffin, and sectioned for hematoxylin and eosin (H\&E) staining, in situ hybridization, and immunohistochemical staining. Animals 12E, 14E, and 17E were not perfused, and their tissues were fixed in formalin. Macaques were divided into three groups; group 1 consisted of macaques inoculated with either of the closely related virus strains SIV/R71 or SIV/17E-Br, group 2 consisted of macaques inoculated with clone SIV/17E-Cl, and group 3 consisted of macaques inoculated with clone SIV/17E-Fr. Macaques with histological evidence of pulmonary opportunistic infections (eg, Pneumocystis carinii or cytomegalovirus) were excluded from the study. Area of lung tissue examined ranged from $121 \mathrm{~mm}^{2}$ to $822 \mathrm{~mm}^{2}$. H\&E-stained sections of lung were evaluated in a blinded fashion independently by two observers (MCZ and JLM), and histological changes were scored as follows: $0=$ none, $1=$ mild, and $2=$ moderate to severe. Scoring reflected both severity and extent of distribution under each of the following categories: 1) interstitial infiltrates of lymphocytes and macrophages, 2) perivascular infiltrates of lymphocytes and macrophages, 3) presence of multinucleated giant cells, and 4) expansion of bronchus-associated lymphoid tissue. The sum of these scores yielded a total lesion severity score with a maximum possible of 8 .

\section{In Situ Hybridization}

Fixed, paraffin-embedded tissue sections were pretreated with $0.2 \mathrm{~N} \mathrm{HCl}$, followed by $30 \mu \mathrm{g} / \mathrm{ml}$ of proteinase $\mathrm{K}$ (Boehringer Mannheim, Indianapolis, IN), and were acetylated, dehydrated, and air dried as previously described. ${ }^{17}$ In situ hybridization was performed using a 792-bp polymerase chain reaction probe amplified from SIVmac239 from a region of the long terminal repeat that hybridizes with all of the viruses used in this study. Primers used for amplification, from bases 9333 to 10125 , were 5'-GTAGTCGACGCGGCCGCAAAATGGGTGGAGCTAT-3' and 5'-GTAGTCGACGCGGCCGCTCATCAGCGAGTTTCCT-3'. The DNA was labeled by random priming with digoxigenin using the DIG/Genius labeling and detection kit (Boehringer Mannheim). Concentration of the labeled probe was approximately $1 \mathrm{ng} / \mu \mathrm{l}$. Labeled DNA $(0.2 \mu \mathrm{g} / \mathrm{ml})$ was denatured, and hybridization was performed overnight at $37^{\circ} \mathrm{C}$. After washing, anti-digoxigenin antibody was applied for 2 hours at room temperature followed by the addition of color substrate solution to slides for 3 hours. Slides were then counterstained with 
nuclear fast red, dehydrated, and coverslipped. Uninfected and SIV-infected tissues and a nonspecific digoxigenin-labeled probe (Borna disease virus) were used as controls. Sections were scored as follows: $0=$ no positive cells, $1=$ an average of two or fewer positive cells per high-power field (hpf), and $2=$ three or more positive cells per hpf.

\section{Immunohistochemistry}

A monoclonal antibody that detects SIV gp41 (designated kk41, a gift of K. Kent, Wells Medical Limited, Royal Tunbridge Wells, UK) was used to assay viral protein in tissues. Cells containing cytotoxic granules (cytotoxic $T$ cells and natural killer cells) were identified by use of an antibody directed against the 15-kd form of the TIA-1 molecule (Coulter), a component of the cytotoxic granules of both cytotoxic $T$ lymphocytes and natural killer cells. ${ }^{23}$ For combined immunohistochemistry and in situ hybridization, anti-ferritin antibody (DAKO, Carpinteria, CA) was used to identify macrophages followed by in situ hybridization with a digoxigenin-labeled SIV DNA probe as described above. Tissues were pretreated for antigen retrieval by heating in a microwave for 8 minutes in a solution of $1 \mathrm{mmol} / \mathrm{L}$ ethylenediaminetetraacetic acid $(\mathrm{pH}$ 8.0; TIA-1) or in $0.01 \mathrm{~mol} / \mathrm{L}$ sodium citrate buffer (kk41). Immunohistochemistry was performed using the avidinbiotin complex technique (Vector Laboratories, Burlingame, CA) with peroxidase as the substrate for color reaction with either 3,3'-diaminobenzidine tetrahydrochloride or with Vector SG (Vector) as substrate for peroxidase. Appropriate isotype tissue controls were used. Sections were scored as follows: $0=$ no positive cells, $1=$ an average of two or fewer positive cells per hpf, and $2=$ three or more positive cells per hpf. The scores for in situ hybridization to detect viral RNA and immunohistochemistry to detect viral antigen were totaled to obtain a score for total virus gene expression, with a maximum possible of 4 . Sections stained for TIA-1 were scored as follows: $0=$ no positive cells, $1=$ up to 5 positive cells per hpf, $2=6$ to 10 positive cells per hpf, and $3=$ more than 10 positive cells per hpf. For double immunolabeling, tissues were heated in a microwave for 8 minutes in $0.01 \mathrm{~mol} / \mathrm{L}$ sodium citrate and then incubated with TIA-1 (Coulter) followed by alkaline phosphatase-conjugated secondary antibody (Kirkegaard \& Perry Laboratories, Gaithersburg, MD) with nitroblue tetrazolium/X-Phosphate (Boehringer Mannheim) as color substrate. For subsequent detection of macrophages, tissues were then incubated with anti-CD68 (DAKO) followed by peroxidase-conjugated secondary antibody (Kirkegaard \& Perry) and color detection with 3-amino-9-ethylcarbazole (Sigma Chemical Co., St. Louis, MO) as substrate.

\section{Results}

\section{Clinical Signs and Immune Status}

Overt signs of respiratory disease (ie, dyspnea, coughing, and nasal discharge) were not observed in these
Table 1. Pulmonary Lesions and Virus Gene Expression in 20 Macaques Inoculated with Macrophage-Tropic SIV

\begin{tabular}{|c|c|c|c|c|}
\hline $\begin{array}{c}\text { Identification } \\
\text { no. }\end{array}$ & Virus & $\begin{array}{l}\text { Days after } \\
\text { inoculation }\end{array}$ & $\begin{array}{l}\text { Lesion } \\
\text { severity* }\end{array}$ & $\begin{array}{l}\text { Virus gene } \\
\text { expression }\end{array}$ \\
\hline \multicolumn{5}{|l|}{ Group 1} \\
\hline 9102 & SIV/17E-Br & 812 & 5 & 0 \\
\hline 9002 & SIV/17E-Br & 804 & 4 & 0 \\
\hline $12 \mathrm{E}$ & SIV/R71 & 129 & 3 & 4 \\
\hline $14 \mathrm{E}$ & SIV/R71 & 304 & 3 & 3 \\
\hline 9003 & SIV/17E-Br & 461 & 3 & 0 \\
\hline 9101 & SIV/17E-Br & 750 & 2 & 1 \\
\hline 9001 & SIV/17E-Br & 776 & 2 & 0 \\
\hline 17E & SIV/R71 & 119 & 1 & 2 \\
\hline \multicolumn{5}{|l|}{ Group 2} \\
\hline M684 & SIV/17E-CI & 813 & 5 & 1 \\
\hline M693 & SIV/17E-CI & 651 & 1 & 1 \\
\hline N862 & SIV/17E-CI & 679 & 1 & 0 \\
\hline M458 & SIV/17E-CI & 981 & 0 & 1 \\
\hline \multicolumn{5}{|l|}{ Group 3} \\
\hline G060 & SIV/17E-Fr & 279 & 5 & 1 \\
\hline M819 & SIV/17E-Fr & 280 & 5 & 1 \\
\hline M069 & SIV/17E-Fr & 272 & 4 & 1 \\
\hline M907 & SIV/17E-Fr & 301 & 3 & 1 \\
\hline L859 & SIV/17E-Fr & 117 & 2 & 2 \\
\hline L839 & SIV/17E-Fr & 272 & 2 & 1 \\
\hline L745 & SIV/17E-Fr & 588 & 2 & 2 \\
\hline $\mathrm{H} 178$ & SIV/17E-Fr & 64 & 0 & 0 \\
\hline
\end{tabular}

*Lesion severity score was derived by scoring histological changes as follows: $0=$ none, $1=$ mild, and $2=$ moderate to severe under each of the following categories: 1) interstitial infiltrates of lymphocytes and macrophages, 2) perivascular infiltrates of lymphocytes and macrophages, 3) presence of multinucleated giant cells, and 4) expansion of bronchus-associated lymphoid tissue. The maximum possible score is 8 .

†Tissues stained for viral antigen or viral RNA were graded as follows: $0=$ no positive cells, $1=$ two or fewer positive cells per hpf, and 2 = three or more positive cells per hpf. Scores for each of these categories were added to obtain the score for virus gene expression. The maximum possible score is 4

animals, which were housed in confinement with limited opportunity for physical exertion. Two macaques (nos. $17 \mathrm{E}, 9003$ ) were euthanized for severe weight loss. All five macaques inoculated with SIV/17E-Br were monitored for immunosuppression by serial analysis of peripheral CD4+ T-cell counts for 2 years after inoculation. Only two, nos. 9001 and 9101, had final CD4+ T-cell counts less than $5 \%$ of preinoculation values (61 and $94 \mathrm{cells} / \mu$ l, respectively), reflecting marked immunosuppression (see Table 3).

\section{Histopathology}

The macaques were divided into two broad groups for comparison of histopathological lesions. Animals with total pulmonary lesion scores of 3 or more were considered to have moderate to severe pneumonia; those with scores of less than 3 were considered to have mild or no pneumonia. Using this classification, 10 of the 20 macaques $(50 \%)$ in this study had moderate or severe pneumonia (Table 1). This group was composed of $62 \%$ of the macaques inoculated with SIV/17E-Br or SIV/R71 (group 1 ), $25 \%$ of the macaques inoculated with SIV/17E-CI (group 2), and $50 \%$ of the macaques inoculated with 

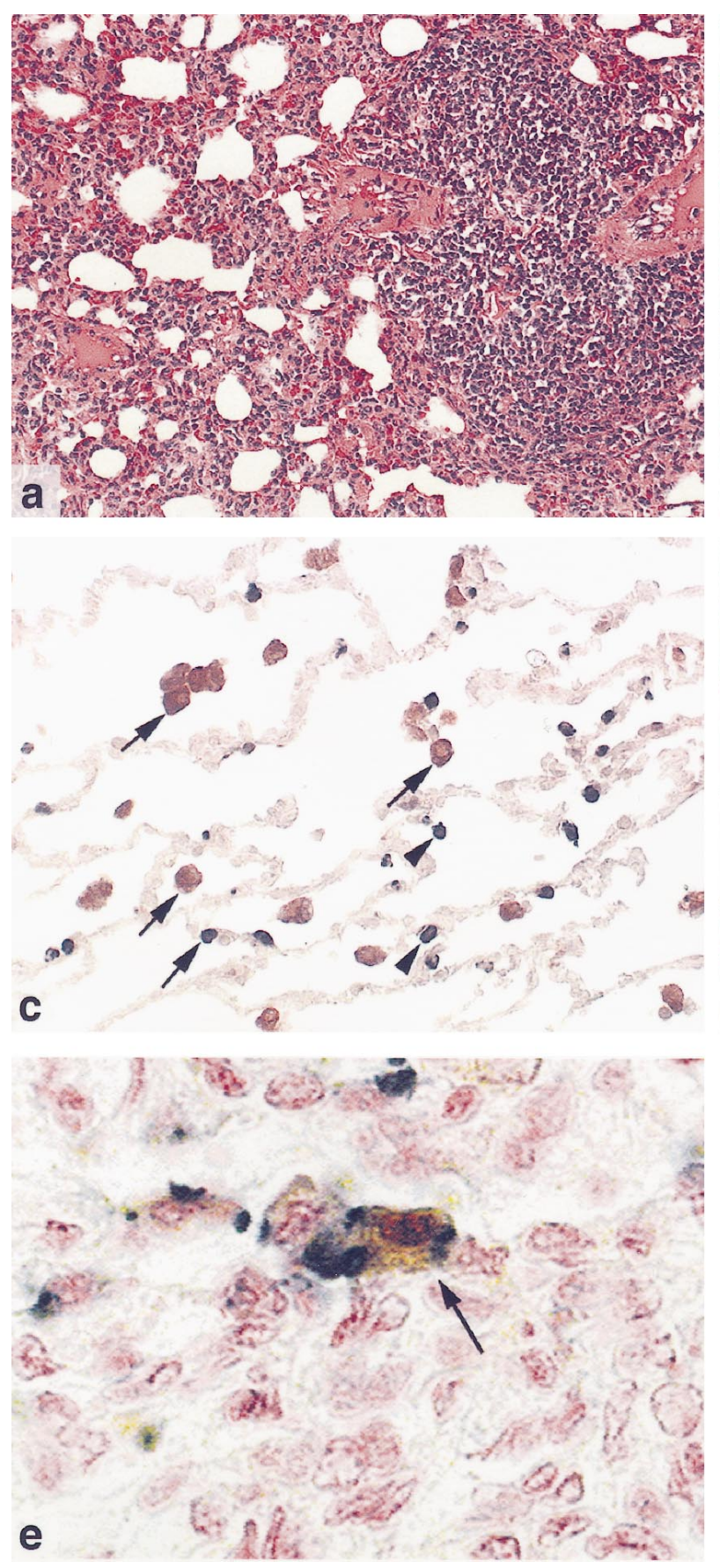

SIV/17E-Fr (group 3). The most common lesion was multifocal, perivascular infiltration of lymphocytes and macrophages, commonly centered on small arterioles, frequently radiating into and expanding adjacent interalveolar septa (Figure 1a). In severely affected macaques, pulmonary architecture was regionally effaced by this coalescing inflammatory infiltrate. Multinucleated giant cells in alveoli and in interalveolar septa were identified in 9 (45\%) of the 20 animals. Eight of the 9 animals with multinucleated giant cells had lesion severity scores of 3 or higher. Expansion of bronchus-associated lymphoid tissue was noted in 9 animals (45\%). Occasionally, lymphocytes were found traversing respiratory epithe-
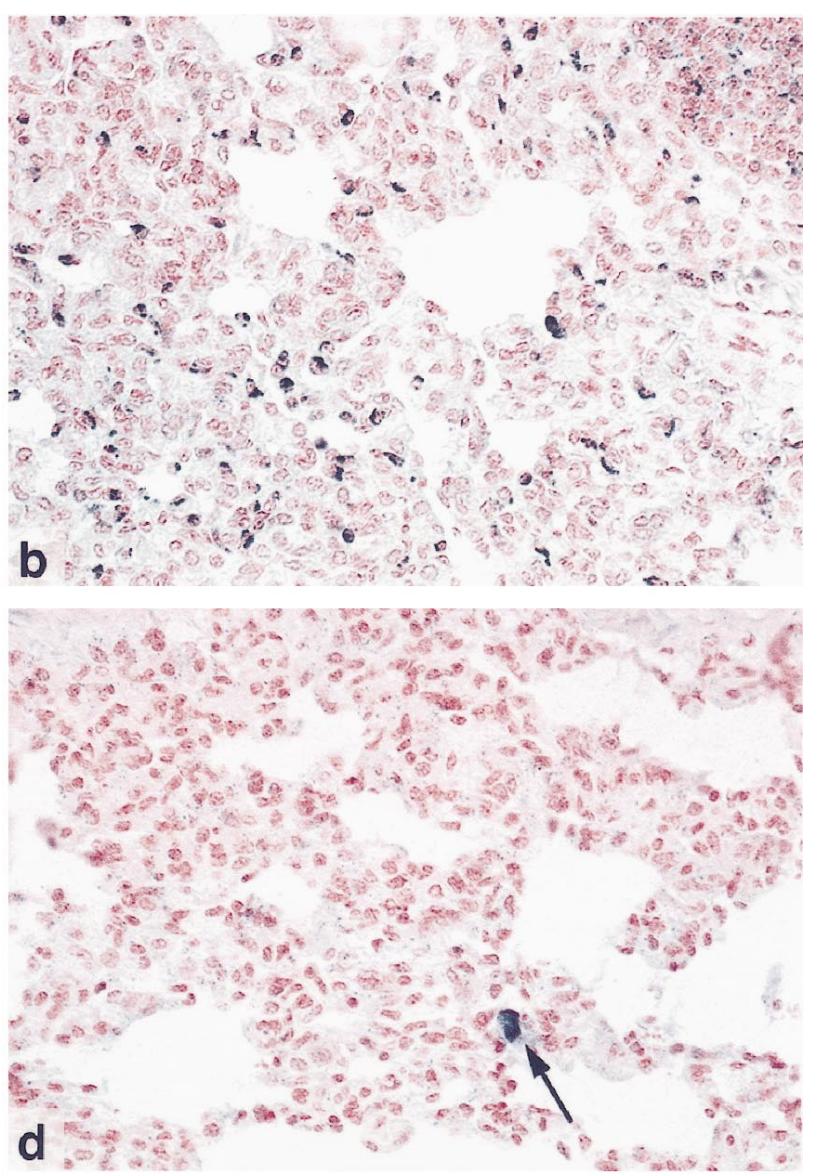

Figure 1. a: Pulmonary lesions in SIV-inoculated macaques are characterized by perivascular and interstitial infiltrates of lymphocytes and macrophages. Macaque $14 \mathrm{E}, \mathrm{H} \& \mathrm{E}$, magnification $\times 100$. b: Immunohistochemical staining for TIA-1, a cytotoxic granule marker, detects high numbers of positive cells in the pulmonary interstitial inflammatory infiltrate. Macaque $14 \mathrm{E}$, nuclear fast red counterstain, magnification $\times 200$. c: Double immunolabeling demonstrates that cells staining for TIA-1 (blue; arrowheads) are distinct from pulmonary macrophages identified by an anti-CD68 monoclonal antibody (red; arrows). Magnification $\times 200$. d: In situ hybridization for viral RNA showing an occasional positive cell (arrow) amid numerous inflammatory cells. Macaque $14 \mathrm{E}$, nuclear fast red counterstain, magnification $\times 200$. e: Double labeling consisting of immunohistochemical staining for the macrophage marker ferritin (brown) and in situ hybridization for viral RNA (blue) shows a macrophage containing viral mRNA. Macaque $14 \mathrm{E}$, nuclear fast red counterstain, magnification $\times 500$.

lium. A large number of the perivascular and interstitial infiltrating mononuclear cells in macaques with moderate to severe pneumonia were cytotoxic lymphocytes as demonstrated by immunohistochemical staining for TIA-1, a component of the cytotoxic granules of cytotoxic $T$ lymphocytes and natural killer cells (Figure 1b). ${ }^{23}$ The majority of the TIA-1-positive cells were presumed to be cytotoxic T cells, because it is unlikely that natural killer cells would be the dominant cell type in this infiltrate. Double immunolabeling was performed to confirm that cells staining positive for TIA-1 were distinct from the pulmonary macrophages (Figure 1c). The number of TIA-1-positive cells increased with increasing severity of 
Table 2. Comparison of Pathological Lesions, Virus Gene Expression, and Cytotoxic Cell Infiltrates

\begin{tabular}{|c|c|c|c|c|c|c|c|c|c|c|}
\hline \multirow[b]{2}{*}{ Group } & \multirow[b]{2}{*}{ Virus inoculum } & \multirow[b]{2}{*}{$n$} & \multicolumn{4}{|c|}{$\begin{array}{l}\text { Macaques with no or mild } \\
\text { pneumonia }\end{array}$} & \multicolumn{4}{|c|}{$\begin{array}{l}\text { Macaques with moderate or severe } \\
\text { pneumonia }\end{array}$} \\
\hline & & & $n$ & $\begin{array}{l}\text { Mean lesion } \\
\text { score }\end{array}$ & $\begin{array}{l}\text { Mean virus } \\
\text { score }\end{array}$ & $\begin{array}{c}\text { Mean } \\
\text { cytotoxic cell } \\
\text { infiltrate* }\end{array}$ & $n$ & $\begin{array}{l}\text { Mean lesion } \\
\text { score }\end{array}$ & $\begin{array}{l}\text { Mean virus } \\
\text { score }\end{array}$ & $\begin{array}{c}\text { Mean } \\
\text { cytotoxic cell } \\
\text { infiltrate* }\end{array}$ \\
\hline 1 & SIV/17E-Br/R71 & 8 & 3 & 1.7 & 1.0 & 1.7 & 5 & 3.6 & 1.4 & 2.6 \\
\hline 2 & SIV/17E-Cl & 4 & 3 & 0.7 & 0.7 & 1.0 & 1 & 5.0 & 1.0 & 1.0 \\
\hline 3 & SIV/17E-Fr & 8 & 4 & 1.5 & 1.2 & 1.2 & 4 & 4.2 & 1.0 & 2.0 \\
\hline All macaques & & 20 & 10 & 1.3 & 1.0 & 1.3 & 10 & 4.0 & 1.2 & 2.2 \\
\hline
\end{tabular}

${ }^{*}$ Tissues stained for the cytotoxic cell marker TIA-1 were graded as follows: $0=$ no positive cells, $1=$ up to 5 positive cells per hpf, $2=6$ to 10 positive cells per hpf, and $3=10$ or more positive cells per hpf. The maximum possible score is 3 ; these scores are means of all animals in these groups.

interstitial and perivascular inflammation, but not with increased bronchus-associated lymphoid tissue expansion.

\section{Virus Gene Expression}

To examine virus gene expression, in situ hybridization and immunohistochemical staining were performed to detect viral RNA and antigen, respectively. Fourteen of the 20 macaques $(70 \%)$ had evidence of virus gene expression in the lung (Table 1, Figure 1d). Seven of these 14 macaques had moderate to severe SIV pneumonia; the other 7 did not have significant lesions despite evidence of virus gene expression (Table 1). Viral RNA was detected in $12(60 \%)$ macaques, and viral protein was detected in $6(30 \%)$. Double staining demonstrated that the vast majority of cells that were positive for vRNA were macrophages (Figure 1e).

\section{Data Analysis}

As there is evidence that various species of macaques respond differently to SIV, a Fisher's exact test was run to assess the possibility of species-specific effect across pneumonia outcome. The result of this test $(P=0.192)$ indicates that there is not a significant association between macaque species and the likelihood of developing pneumonia after inoculation with SIV.

To examine the relationship between severity of pulmonary lesions and virus gene expression, mean lesion severity scores and mean pulmonary virus gene expression scores were calculated for macaques with moderate to severe pneumonia and compared with data from macaques with mild or no pneumonia in groups 1,2 , and 3 , respectively (Table 2). Fisher's exact test was used to test for an association between lesion severity and pulmonary viral load regardless of viral strain. There was no significant difference in virus gene expression between macaques with moderate to severe pneumonia and those with mild or no pneumonia $(P=0.33)$. Animals with moderate or severe lesions had a mean virus gene expression score of 1.2, whereas those without significant lesions had a score of 1.0 (Table 2).

To account for the possibility of heterogeneous viral strains affecting the relationship between severity of pneumonia and viral gene expression, the data were also stratified by virus strain. These stratified data were then used to examine the association between pulmonary viral load $(0,>1)$ and lesion severity, both within strata and overall, using exact tests. ${ }^{24}$ All calculations were done in EGRET (Statistics and Epidemiology Research Corp., Seattle, WA). When the exact test was applied to the $2 \times 2$ tables of lesion severity and presence/absence of viral load, stratified by viral strain, all $P$ values testing for association between lesion severity and viral burden were greater than 0.50 , indicating that there was no significant association between lesion severity and pulmonary viral burden for any of the three viral strains in this study.

Similarly, the relationship between pulmonary lesion severity and cytotoxic cell infiltrates was examined by calculating mean lesion scores and mean cytotoxic cell infiltrate scores for animals with moderate to severe pneumonia and comparing the outcome with data from macaques with mild to no pneumonia (Table 2). Fisher's exact test was used to test for an association between lesion severity and pulmonary cytotoxic cell infiltrates and demonstrated a statistically significant association $(P<$ $0.05)$ between lesion severity and cytotoxic cell infiltrate.

To determine whether there was a correlation between immunosuppression and pneumonia, the five macaques inoculated with SIV/17E-Br were ranked for percentage decline in CD4+ T-cell counts and severity of pneumonia. Spearman's rank correlation test demonstrated an inverse relationship $(r=-0.875)$ between the percentage decline in CD4+ T-cell counts and the severity of pneumonia. Kendall's tau test demonstrated that this correlation was statistically significant $(P<0.05)$.

\section{Discussion}

In this study, 10 of 20 macaques inoculated with macrophage-tropic SIVs (replicating in primary macrophages and lymphocytes, but not in T cell lines) developed moderate to severe interstitial pneumonia that resembled HIVinduced LIP. This study demonstrated that, regardless of the virus strain with which the macaques were inoculated, there was no relationship between the severity of the histological lesions and the level of virus gene expression 
Table 3. Inverse Correlation between Lesion Severity and Final CD 4 Cell Counts*

\begin{tabular}{|c|c|c|c|c|}
\hline Identification no. & $\begin{array}{l}\text { Initial CD4+ count } \\
(\text { cells/ } \mu \mathrm{l})\end{array}$ & $\begin{array}{c}\text { Final CD4+ count } \\
(\text { cells/ } \mu l)\end{array}$ & $\begin{array}{l}\% \text { decline in CD4+ } \\
\text { cell count }\end{array}$ & $\begin{array}{c}\text { Lesion severity } \\
\text { score }\end{array}$ \\
\hline 9001 & 1937 & 61 & 97 & 2 \\
\hline 9101 & 3234 & 94 & 97 & 2 \\
\hline 9003 & 1801 & 198 & 89 & 3 \\
\hline 9002 & 1375 & 418 & 70 & 4 \\
\hline 9102 & 2654 & 651 & 75 & 5 \\
\hline
\end{tabular}

${ }^{\star} P<0.05$ by Spearman's rank correlation test and Kendall's tau test.

in the lung. This suggests that the pulmonary lesions were not a direct result of virus replication in the lung, but that other factors contributed to the pulmonary changes. The macrophage- and lymphocyte-rich nature of the pulmonary infiltrates, and the large number of inflammatory cells in the lung that stained immunohistochemically for cytotoxic granules, suggested that SIV pneumonia may represent an immunopathological manifestation of the host's anti-SIV immune responses.

Similar to SIV pneumonia, LIP in HIV-infected individuals is characterized by dense perivascular and interstitial infiltrates of cytotoxic lymphocytes and macrophages. Interestingly, studies of LIP in children have demonstrated a reduced incidence of opportunistic infections and longer survival time in children with LIP than in HIVinfected children without pulmonary lesions. ${ }^{8-10}$ In addition, a study has shown that pulmonary interstitial infiltrates identified by radiography in HIV-infected children with LIP improve or resolve when immunosuppression develops. ${ }^{25}$ Another HIV-associated condition, DILS, characterized by intense CD8+ lymphocytic infiltrates in the lungs and other tissues, is also associated with fewer opportunistic infections and longer survival. One explanation for this finding is that LIP and DILS may be manifestations of an HIV-directed, tissue-specific cytotoxic T lymphocyte response against HIV in the lung. This cytotoxic $T$ lymphocyte response may reflect the ability of an individual's immune system to control viral load on a systemic level, thereby resulting in prolonged survival.

Findings in this study also support this hypothesis. In group 1, the only group for which CD4+ cell counts were monitored throughout infection, the two macaques (nos. 9101 and 9001) with profound immunosuppression (terminal CD4+ cell counts less than $5 \%$ of preinoculation values) had only minimal pulmonary lesions. Interestingly, in one of these macaques, this decline in CD4+ cell counts occurred after the emergence of lymphocytetropic strains of virus (M. C. Zink, unpublished data). In contrast, three other macaques (nos. 9002, 9003, and 9102) inoculated with the same virus, SIV/17E-Br, developed moderate to severe pneumonia without significant immunosuppression (defined as CD4+ cell counts less than $5 \%$ of preinoculation values; Table 3 ). This suggests an inverse relationship between immunocompetence and pneumonia in SIV-infected macaques similar to that described in HIV-infected children.

There is a precedent for the development of immunemediated interstitial pneumonia during virus infections. Mice experimentally infected with respiratory syncytial virus normally clear the virus rapidly. However, respira- tory syncytial virus-infected mice that were given cytotoxic T cells specific to this virus developed more severe pulmonary lesions, implicating cell-mediated immunity in the pathogenesis of respiratory syncytial virus pneumonia. ${ }^{26}$ Thus, HIV and SIV may force the host to choose between conflicting responses. On one hand, robust cellmediated immunity may effectively control virus replication, but organ-specific immunopathology may result. On the other hand, a less robust cell-mediated immune response may spare the host immunopathological insult but will allow more abundant virus replication. Despite the success of host immune mechanisms in prolonging clinical latency, progression to acquired immunodeficiency syndrome usually occurs. HIV-and SIV-associated pneumonia may represent cell-mediated immune responses that are dependent on ongoing CD4+ T cell-mediated help. Thus, decline of helper cell function and numbers may render the host unable to sustain the inflammatory responses in the lungs. If the local response to virus in the lung is representative of effective containment of systemic virus burden, then resolution of lentivirus-induced pneumonia may be a sign of immunological deterioration.

This study of the pathogenesis of SIV-induced pneumonia is unique in that the macaques were all inoculated with macrophage-tropic viruses (defined as having the ability to replicate in primary macrophages and lymphocytes but not in $T$ cell lines). These macrophage-tropic viruses have a less immunosuppressive phenotype than the virus swarms such as SIV/DeltaB670 and SIVmac251 used in other studies of SIV pneumonia, which contain both macrophage-tropic and lymphocyte-tropic phenotypes. ${ }^{20,27,28}$ The prolonged course of disease in the majority of these macaques provides further confirmation of the less immunosuppressive phenotype of these macrophage-tropic viruses. Inoculation with macrophagetropic strains recapitulates natural infection with HIV in which the early viruses detected in the host are macrophage-tropic. ${ }^{29,30}$ The presence of similar histopathological changes in the lungs of the macaques in this study and in previous studies of macaques inoculated with both macrophage- and lymphocyte-tropic strains ${ }^{27,31}$ suggests that the macrophage-tropic viruses are associated with the development of pulmonary lesions. The importance of virus replication in macrophages was confirmed in this study by double labeling, which demonstrated viral RNA almost exclusively in macrophages in the lungs.

Further confirmation of the role of virus infection of macrophages in the development of LIP comes from studies of ovine progressive pneumonia virus and caprine arthritis-encephalitis virus. Unlike HIV and SIV, 
these sheep and goat lentiviruses replicate almost exclusively in macrophages and do not replicate in primary lymphocytes or in T cell lines. ${ }^{32}$ Nonetheless, these viruses commonly cause LIP, which bears similarities to the LIP of SIV-infected macaques and HIV-infected children. ${ }^{33,34}$

A previous study reported high levels of virus gene expression in the lungs of macaques with pneumonia after inoculation with an SIV swarm, SIV/DeltaB670, that contains both macrophage-tropic and lymphocyte-tropic viruses. ${ }^{28}$ Many of the animals in that study were examined at terminal stages of acquired immunodeficiency virus, when the animals are immunosuppressed and there are high levels of replicating virus in peripheral blood cells and in tissues throughout the body. In contrast, animals in this study were inoculated with macrophage-tropic viruses that do not have a strong immunosuppressive phenotype and were examined before the terminal stages of disease. ${ }^{20}$ This may explain the differences seen in virus gene expression in these two reports.

This retrospective study did not specifically examine which arm(s) of the immune system might have contributed to the pulmonary lesions in these macaques. However, the significant infiltrates of cytotoxic lymphocytes in these animals and studies demonstrating large numbers of CD8+ lymphocytes specific for HIV in the lungs of HIV-infected individuals suggest that cell-mediated immune responses may play a particular role in the development of pulmonary lesions.

\section{References}

1. Jason J, Stehr-Green J, Holman RC, Evatt BL, Group H AIDS cohort study Human immunodeficiency virus infection in hemophilic children. Pediatrics 1988, 82:565-570

2. Pizzo P, Eddy J, Faloon J: Acquired immune deficiency syndrome in children. Am J Med 1988, 85(Suppl 2A):195-202

3. Travis WD, Fox CH, Devaney KO, Weiss LM, O'Leary TJ, Ognibene FP, Suffredini AF, Rosen MJ, Cohen MB, Shelhamer J: Lymphoid pneumonitis in 50 adult patients infected with the human immunodeficiency virus: lymphocytic interstitial pneumonitis versus nonspecific interstitial pneumonitis. Hum Pathol 1992, 23:529-541

4. Travis WD, Lack EE, Ognibene FP, Suffredini AF, Shelhamer J: Lung biopsy interpretation in the acquired immunodeficiency syndrome: experience of the National Institutes of Health with literature review. Progress in AIDS Pathology, ed 1. Edited by H Rotterdam, SC Sommers, P Racz, PR Meyer. New York: Field \& Wood, 1989, pp 51-84

5. Plata F, Autran B, Pedroza Martins L, Wain-Hobson S, Denis M, Guillon J-M: AIDS virus-specific cytotoxic T lymphocytes in lung disorders. Nature 1987, 328:348-351

6. Strimlan CV, Rosenow EC, Divertie MB, Harrison EG: Pulmonary manifestations of Sjögren's syndrome. Chest 1976, 70:354-361

7. Yood RA, Steigman DM, Gill LR: Lymphocytic interstitial pneumonia in a patient with systemic lupus erythematosis. Lupus 1995, 4:161-163

8. Arditi M, Kabat W, Yogev R: Serum tumor necrosis factor $\alpha$, interleukin $1-\beta$, p24 antigen concentrations and CD $4+$ cells at various stages of human immunodeficiency virus 1 infection in children. Pediatr Infect Dis 1991, 10:450-455

9. Joshi VV, Oleske JM, Minnefor AB, Saad S, Klein KM, Singh R, Zabala M, Dadzie C, Simpser M, Rapkin RH: Pathologic pulmonary findings in children with the acquired immunodeficiency syndrome. Hum Pathol 1985, 16:241-246

10. Scott GB, Hutto C, Makuch RW, Mastrucci MT, O'Connor T, Mitchell CD, Trapido EJ, Parks WP: Survival in children with perinatally acquired human immunodeficiency virus type 1 infection. New Engl J Med 1989, 321:1791-1796
11. Itescu S, Brancato LJ, Buxbaum J, Gregersen PK, Rizk CC, Croxson S, Solomon GE, Winchester R: A diffuse infiltrative CD8 lymphocytosis syndrome in human immunodeficiency virus (HIV) infection: a host immune response associated with HLA-DR5. Ann Intern Med 1990, 112:3-10

12. Itescu S: Diffuse infiltrative lymphocytosis syndrome in human immunodeficiency virus infection: a Sjögren's-like disease. Rheum Dis Clin North Am 1991, 17:99-115

13. Itescu S, Dalton J, Zhang HZ, Winchester R: Tissue infiltration in a CD8 lymphocytosis syndrome associated with human immunodeficiency virus- 1 infection has the phenotypic appearance of an antigenically driven response. J Clin Invest 1993, 91:2216-2225

14. Stevenson M, Gendelman HE: Cellular and viral determinants that regulate HIV-1 infection in macrophages. J Leukocyte Biol 1994, $56: 278-288$

15. Meltzer MS, Kornbluth RS, Hansen B, Dhawan S, Gendelman HE: HIV infection of the lung: role of virus-infected macrophages in the pathophysiology of pulmonary disease. Chest 1993, 103(Suppl):103S$108 \mathrm{~S}$

16. Desrosiers RC, Hansen-Moosa A, Mori K, Bouvier DP, King NW, Ringler DJ: Macrophage-tropic variants of SIV are associated with specific AIDS-related lesions but are not essential for the development of AIDS. Am J Pathol 1991, 139:29-35

17. Sharma DP, Zink MC, Anderson M, Adams R, Clements JE, Joag SV, Narayan O: Derivation of neurotropic simian immunodeficiency virus from exclusively lymphocytetropic parental virus: pathogenesis of infection in macaques. J Virol 1992, 66:3550-3556

18. Anderson MG, Hauer D, Sharma DP, Joag SV, Narayan O, Zink MC, Clements JE: Analysis of envelope changes acquired by SIVmac239 during neuroadaption in rhesus macaques. Virology 1993, 195:616626

19. Flaherty M, Hauer DA, Mankowski JL, Zink MC, Clements JE: Molecular and biological characterization of a neurovirulent molecular clone of SIV. J Virol 1997, 71:5790-5798

20. Mankowski JL, Flaherty MA, Spelman JP, Hauer DA, Didier PJ, Martin Amedee A, Murphey-Corb M, Munoz A, Clements JE, Zink MC: Pathogenesis of SIV encephalitis: viral determinants of neurovirulence. J Virol 1997, 71:6055-6060

21. Zink MC, Amedee Martin A, Mankowski JL, Craig L, Munoz A, Spelman JP, Didier P, Murphey-Corb M, Carter DL, Clements JE: Simian immunodeficiency virus encephalitis: selection of neurovirulent strains of virus by the central nervous system. Am J Pathol 1997, 151:793-803

22. Martin LN, Murphey-Corb M, Soike M, Davidson-Fairburn B, Baskin GB: Effects of initiation of $3^{\prime}$-azido, $3^{\prime}$-deoxythimidine (zidovudine) treatment at different times after infection of rhesus monkeys with simian immunodeficiency virus. J Infect Dis 1993, 168:825-835

23. Anderson P: TIA-1: structural and functional studies on a new class of cytolytic effector molecule. Curr Top Microbiol Immunol 1995, 198: $131-143$

24. Mehta CR, Patel NR, Gray R: Computing an exact confidence interval for the common odds ratio in several $2 \times 2$ contingency tables. J Am Stat Assoc 1986, 80:969-973

25. Prosper M, Omene JA, Ledlie S, Odita JC: Clinical significance of resolution of chest X-ray findings in HIV-infected children with lymphocytic interstitial pneumonitis (LIP). Pediatr Radiol 1995, 25:S243S246

26. Cannon MJ, Openshaw PJM, Askonas BA: Cytotoxic T cells clear virus but augment lung pathology in mice infected with respiratory syncytial virus. J Exp Med 1988, 168:1163-1168

27. Baskerville A, Ramsay AD, Addis BJ, Dennis MJ, Cook RW, Cranage MP, Greenaway PJ: Interstitial pneumonia in simian immunodeficiency virus infection. J Pathol 1992, 167:241-247

28. Baskin GB, Murphey-Corb M, Martin LN, Soike KF, Hu F-S, Kuebler D: Lentivirus-induced pulmonary lesions in rhesus monkeys (Macaca mulatta) infected with simian immunodeficiency virus. Vet Pathol 1991, 28:506-513

29. Zhu T, Mo H, Wang N, Nam DS, Cao Y, Koup RA, Ho DD: Genotypic and phenotypic characterization of HIV-1 in patients with primary infection. Science 1993, 261:1179-1181

30. Roos MTJ, Lange JMA, deGoede REY, Coutinho RA, Schellekens PTA, Miedema F, Tersmette M: Viral phenotype and immune response in primary human immunodeficiency virus type 1 infection. J Infect Dis 1992, 165:427-432 
31. Baskerville A, Ramsay A, Cranage MP, Cook N, Cook RW, Dennis MJ, Greenaway PJ, Kitchin PA, Stott EJ: Histopathological changes in simian immunodeficiency virus infection. J Pathol 1990, 162:67-75

32. Gorrell MD, Brandon MR, Sheffer D, Adams RJ, Narayan O: Ovine lentivirus is macrophage tropic and does not productively infect $T$ lymphocytes. J Virol 1992, 66:2679-2688
33. Lujan L, Begara I, Collie DDS, Watt NJ: CD8+ Iymphocytes in bronchoalveolar lavage, and blood: in vivo indicators of lung pathology caused by maedi-visna virus. Vet Immunol Immunopathol 1995, 49: $89-100$

34. Zink MC, Yager JA, Myers JD: Pathogenesis of caprine arthritis encephalitis virus: cellular localization of viral transcripts in tissues of infected goats. Am J Pathol 1990, 136:843-854 